\title{
Stage III Soft Tissue Sarcoma of the Trunk and Extremities AJCC v8
}

National Cancer Institute

\section{Source}

National Cancer Institute. Stage III Soft Tissue Sarcoma of the Trunk and Extremities

A/CC v8. NCl Thesaurus. Code C136702.

Stage III includes: IIIA: (T2, N0, M0, G2, G3); IIIB: (T3, T4, NO, M0, G2, G3). T2: Tumor measuring more than $5 \mathrm{~cm}$ and less than or equal to $10 \mathrm{~cm}$ in greatest dimension. T3: Tumor measuring more than $10 \mathrm{~cm}$ and less than or equal to $15 \mathrm{~cm}$ in greatest dimension. T4: Tumor measuring more than $15 \mathrm{~cm}$ in greatest dimension. N0: No regional lymph node metastasis or unknown lymph node status. M0: No distant metastasis. G2: Total differentiation, mitotic count and necrosis score of 4 or 5. G3: Total differentiation, mitotic count and necrosis score of 6, 7, or 8. (AJCC 8th ed.) 